\title{
Czech Surrealism and Czech New Wave Realism
}

\author{
By Alison Frank \\ Fall 2011 Issue of KINEMA \\ CZECH SURREALISM AND CZECH NEW WAVE REALISM: THE IMPORTANCE OF
OBJECTS
}

\begin{abstract}
This article examines a major difference between French and Czech Surrealism as exemplified by their attitudes to film. It engages in a close analysis of three films by documentary-influenced Czech New Wave directors whom the Prague Surrealist group admired: Miloš Forman, Ivan Passer and Jan Němec. The analysis focuses on the way in which objects in these films can take on multiple meanings depending on their context. It concludes that such objects suggest a broadening of possibilities in everyday life and in this respect correspond to both Surrealist goals and to the experience of living in a society in the process of political liberalization.
\end{abstract}

The Paris Surrealist group's favourite Czech New Wave film was Věra Chytilová's highly experimental Sedmikrásky (Daisies, 1966); the Prague group, by contrast, preferred the documentary-style approach of Miloš Forman and Ivan Passer (Král 2002: 9). The Prague Surrealists also extended their praise to the somewhat less realistic films of Jan Němec, but only insofar as their 'onirisme inclut [...] un sens des réalités crus/their oneirism included [...] a sense of raw reality' (Král 2002: 9). This difference of opinion between the Paris and Prague Surrealist groups points to a more profound divergence in their cultural and historical origins. In this article I will begin by exploring this divergence and go on to explain how it influenced the Prague group's attitude to cinema. I will then examine one film by each of the three directors that the Prague group singled out for praise: Miloš Forman's Lásky jedné plavovlásky (Loves of a Blonde, 1965), Ivan Passer's Intimní osvětlení (Intimate Lighting, 1965) and Jan Němec's O slavnosti a hostech (The Party and the Guests, 1966). The analysis will focus on the way in which Forman, Passer and Němec make use of physical objects in their films: familiar items take on numerous different meanings in relation to their context and the characters' preoccupations. I believe that part of the appeal that these films held for the Czech Surrealists was the way in which the directors deployed physical objects to demonstrate the rich multiplicity of meaning inherent in our everyday surroundings, an idea which was cherished by both Paris and Prague Surrealist groups.

The Origins of the Czech Surrealist emphasis on reality

As their differing tastes in cinema suggest, the major difference between French and Czech approaches to Surrealism lay in their relationship to physical reality. The Paris group at times became distanced from physical reality, allowing the unconscious (and its associated creativity) to take precedence (Král 1983: 18). The Prague group's attitude, by contrast, was eloquently summarised by Vratislav Effenberger, one of their post-war leaders: 'Imagination does not mean turning away from reality but its antithesis: reaching through to the dynamic core of reality' (Hames 2008b: 34). The origin of the Prague Surrealist group's affinity for reality can be attributed to several distinct factors in its development.

To begin, it is necessary to look to the forerunners of the respective Surrealist groups. While Surrealism in Paris developed from Dada, in Prague it grew from a specifically Czech movement known as Poetism. Poetism was itself part of a larger avant-garde movement in Czechoslovakia known as Devětsil. Like Dada, Devětsil reacted to the barbarity of World War I by rejecting Western culture and technology (Šmejkal 1990b: 10). Devětsil did not share Dada's nihilism, however, as it found a viable alternative to that which it had rejected: leftist politics, folk art, and traditional lifestyles with their emphasis on simple pleasures (Šmejkal 1990b: 10).

Devětsil's orientation changed radically within two years of its foundation. By 1922, the movement's leader Karel Teige and poet Vítězslav Nezval began to promote Constructivist approaches which privileged the very technology Devětsil had initially rejected (Šmejkal 1990b: 12,18). What remained unchanged, however, was the group's focus on real-life concerns: where Devětsil had initially embraced reality by turning to simple pleasures and popular art forms, a similar concern for everyday reality was subsequently reflected in the modern utilitarian approach of Constructivism. 
In 1924, Poetism developed within Devětsil as a freer, more playful and imaginative complement to Constructivism's austere discipline (Hames 2009: 169). The Poetists' characteristic 'désir du réel/desire for what is real' manifested itself in a hedonistic lifestyle (Král 1983: 14) which continued Devětsil's attachment to physical reality.

The Constructivist element had initially made Devětsil irreconcilable with French Surrealism but the late 1920s saw changes in both groups' ideas, bringing them closer together: Teige's Druhý manifest poetismu (Second Manifesto of Poetism, 1927-28) described a developing interest in the role of the unconscious, while André Breton's Second manifeste du surréalisme (Second Surrealist Manifesto, 1929) reflected a commitment to dialectical materialism (Šmejkal 1989: 66; Šmejkal 1990b: 19). Following a meeting in Paris with Breton, Nezval founded the Czech Group of Surrealists in 1934, with an 'official programme' declaring the group's allegiance to the Communist Party, while maintaining its right to artistic freedom (Šmejkal 1990a: 88).

While political ideals were a strong influence on the Czech avant-garde's commitment to reality up to the beginning of World War II, political trauma during and after the war would bring a marked change to the Czech Surrealists' relationship to the physical world. Their experience of oppression under Nazism and Stalinism altered their formerly joyful, optimistic outlook (Hames 2008c: 110). As a result, they came to focus on the most oppressive aspects of reality, in which any symbolism present consisted of shifting meanings that would mislead the observer (Král 1983: 45, 50). At the same time, compared with the abstract absurdities practiced by the governing powers, tangible physical surroundings, however bleak in appearance, were reassuring (Král 1983: 41, 50).

\section{Czech surrealism and the Czech New Wave}

Czech Surrealism had little direct influence on the films of the Czech New Wave. This is not to say that Czech Surrealism and its avant-garde precursors were not adopted by Czech New Wave film-makers as one of a variety of cultural references: films cited as surrealist-inspired include Jaromil Jireš's Valerie a týden divů (Valerie and her Week of Wonders, 1970), Štefan Uher's Panna zázračnica (The Miraculous Virgin, 1966), Jan Němec's Mučedníci lásky (Martyrs of Love, 1966) and Démanty noci (Diamonds of the Night, 1964) and, of course, Chytilová's Daisies (Hames 2009: 168-172). Although the Surrealist Group was still active in 1960s Czechoslovakia, these films mainly reflect the avant-garde in its earlier manifestations: pre-war Czech Surrealism or, in the case of Martyrs of Love, Poetism (Hames 2008b: 28). Most of these films cannot be said to have genuinely adopted the concerns of Surrealism, pre- or post-war: rather, as Michal Bregant puts it, they simply borrow Surrealism's 'stéréotypes esthétisants/aesthetic stereotypes' (1996: 83). Contemporary Surrealists were, moreover, keen to distance themselves from such superficial manifestations: Effenberger, for example, criticised Chytilová for 'mere eclecticism' and 'decorative cynicism' in her work (Škvorecký 1971: 112; Hames 2009: 179).

A more profound contemporary concern shared by the Czech Surrealist group and the Czech New Wave was physical reality. The origins of Czech Surrealism's engagement with the material world were outlined in detail in the previous section. For Czech New Wave film-makers, the liberalization of culture that took place in the 1960s brought with it the permission to portray contemporary reality, complete with all its contradictions and complexities (Král 2002: 8-9). The liberalization was not complete, however, so the films often conveyed their meaning in an ambiguous manner in order to pass by the censors. As a result, not only objects but words, situations and characters in Czech New Wave films could be interpreted in more than one way. As Ivan Passer put it, censorship 'forces filmmakers to find a language which the censors don't pick up on immediately and because of that the language becomes ambivalent - it is able to express more than just definitions' (Buchar 2004: 146).

For the Czech Surrealists, documentary-style film-making was perfectly suited to convey the rich variety of meaning that they perceived in everyday reality. Karel Vachek, a director on the fringes of the Czech New Wave, was esteemed by Effenberger for his observational approach and the attentiveness it encouraged in the audience: as they are uncertain whether or not what they are seeing is symbolic, their imagination is mobilised, scrutinising the reality portrayed for possible meanings (Král 2002: 9; Effenberger qtd. in Král 2002: 40-41). While this attitude corresponds to the Surrealist belief in a creative relationship between individuals and the material world, it also points to the sense that objects are resistant to interpretation. In the early days of Czech Surrealism, Nezval emphasised 'la seule presence de l'objet/the simple presence of the 
object' and its 'matérialité unique/unique material qualities' over any form of interpretation (Král 1983: 20). Later, under Communism, the Surrealists' sense of the 'irréductible mystère des choses/irreducible mystery of things' served as a refreshing alternative to the dogma of the authoritarian regime (Král 1983: 41). Jan Švankmajer, director and practising Surrealist, believes that objects have an independent inner life, and that it is the director's job to draw out this inner life (Hames 2008a: 99), yet it is notable that objects in his films always maintain a large degree of mystery.

Post-war, the Czech Surrealists saw reality as inherently absurd, and believed that by representing this reality in the most direct manner in art, a natural 'objective humour' would emerge (Hames 2008b: 35): the result would be a 'critique par l'absurdité/critique by absurdity' (Král 1983: 33). It was this approach to satirising contemporary reality that Effenberger admired in Forman's work: he praised the director's 'active understanding of reality, ... feeling for contemporary forms of aggressive humour, and for the critical functions of absurdity' (qtd. in Škvorecký 1971: 91). Although Forman, Passer and Němec take a comic approach, and so do not cast objects as particularly weighty or mysterious, they do develop multiple possible meanings or interpretations in relation to the everyday items that appear in their films. In the following three analyses, I hope to identify an additional element of the documentary-inspired Czech New Wave films which may have appealed to the Czech Surrealists: the way in which they reveal the multiple meanings inherent in the objects that surround us in everyday life.

\section{Miloš Forman's Loves of a Blonde}

Miloš Forman, Ivan Passer and Jaroslav Papoušek were collectively known as 'the Forman School': they regularly collaborated on each other's films, and shared a concern with the realistic portrayal of contemporary life (Buchar 2004: 9). Although many Czech New Wave films had tendencies towards documentary realism, the Forman School's films were most consistent in their focus on the everyday (Hames 2005: 106).

The Forman School's films point to the multiple layers of physical reality in general, not just in relation to objects. The Czech Surrealists liked the way in which these films 'découvrent la face cachée du réel, son comique ou sa monstruosité latents à même ses accidents, ses bégaiements et flottements quotidiens/uncover the hidden side of reality, its comical or monstrous quality which lies just beneath everyday mishaps, stutters and waverings' (Král 2002: 9).

Forman's Loves of a Blonde follows the love life of adolescent factory employee Andula, who lives in a girls' hostel in a small town. The film opens with a warm and intimate scene between Andula and her friend as they lie in bed together discussing Andula's boyfriend Tonda. The opening of the next scene creates a startling contrast with the first as it shifts to a bright snowy forest in daylight, with no people present. The camera pans and comes to rest on a necktie knotted around a tree. The tie is drawn to the audience's attention not only by the camera work, but because it is an object that is out of place. An unusual juxtaposition is created, one which invites the audience to compare the tree trunk to a human neck. When a passing forester finds that Andula was responsible for placing the tie around the tree, his objections have a ridiculous basis and make a mockery of inane official regulation that seems designed to crush spontaneity.

The explanation for this surreal juxtaposition of tie and tree comes only in the next scene, which returns to the two girls in bed and reveals that the previous scene was a flashback. Andula tells her friend that she had left the tie on the tree as a present for Tonda, but not only did he never receive it, in the attempt to give it to him Andula considered replacing him with the forester. In retrospect, the scene in the forest is more comical: the forester's exchange with Andula became playfully flirtatious towards the end, and as the necktie formed the pretext for their conversation, it points to the fact that an object can have multiple functions, from being a gift for one lover to inviting a chance encounter with another. Moreover, the manner in which the tie itself is situated in the natural context of the forest can be seen as having an erotic as well as a comic effect, as the tree trunk takes on a phallic resonance.

The same tie makes a second appearance near the end of the film, when Andula goes unannounced to visit to her new love interest, Milda, in Prague. Milda's mother discovers the tie in Andula's suitcase where it is again an object out of place, as it is an unusual item of clothing to find in a girl's bag. While the audience may assume that Andula is planning to give Milda the gift that she never gave to her last boyfriend, the camera's focus on the mother's face suggests an alternate point of view: she may think that it is something that Milda left behind when he slept with Andula, and thus interpret it as evidence of the sexual nature of 
their relationship. There is again, in relation to this interpretation of the tie, a stark and comical contrast, this time between the mainly tranquil, loving and intimate night that Andula and Milda did indeed spend together before, and Andula's present stay at Milda's parents' house, where she is treated as an unwelcome guest and must sleep alone while the family bickers endlessly around her.

An object which recurs more frequently in the film is a ring. Like the tie, it demonstrates that a familiar object may take on multiple meanings depending on a character's personal preoccupations. The conversation between Andula and her friend in the first scene revolves around the ring that Tonda gave Andula as a present. A comic element of doubt is introduced to the ring's traditional connotation of a serious relationship: the friend asks 'Is it real gold?' and Andula assures her of its authenticity with youthful naïveté. In relation to this first scene, the ring's second appearance questions the object's connotations much more radically. This time, Andula is lying in bed with Milda, and as they admire each other's rings, both claim that they were presents from their mothers. As this is the same ring that Andula identified in the first scene as a present from her boyfriend, the audience knows that Andula is lying to Milda, just as he may be lying to her.

On the other two occasions when rings are foregrounded, the film more directly undermines the assumption that a ring signifies commitment. The first occasion comes just before Andula and Milda spend the night together. Andula's employer organises a dance, but as men outnumber women in the town, he asks the army to send some soldiers. Unfortunately, most of the soldiers are middle-aged reservists, many of whom are married. Keen to seduce some younger women, one of them tries discreetly to remove his wedding band, but winds up having to chase it around the dance floor. This comical episode demonstrates that one may take advantage of the fact that a ring can be removed, and its associated symbolism of commitment temporarily suspended. Later, after Andula has slept with Milda, she makes a more definitive statement by ceasing to wear the ring that Tonda gave her. Childishly embarrassed when he confronts her about it, Andula denies the symbolism of the ring. She forces Tonda to admit that the ring is hers, and that she therefore has the right to decide when she wants to wear it.

\section{Ivan Passer's Intimate Lighting}

In Passer's Intimate Lighting, the repetition of objects is less clear: rather than a single object making repeated appearances, it is objects of a similar category that recur. Even more than Loves of a Blonde, Intimate Lighting highlights the difference between life in Prague and life in the countryside. It does so through a narrative centred on a visit made by the urbanite Petr and his girlfriend Štěpa to Petr's former classmate Bambas, a family man who lives in the country. With even less narrative momentum than Loves of a Blonde, rather than focusing on events the film gives a sense of the atmosphere and experience of the visit, both for the visitors and their hosts. The springs in Intimate Lighting's mechanism are its interpersonal dynamics, the chief of which is the contrast between the two old friends, who are both musicians. While Petr's life in Prague offers artistic opportunities and unfixed relationships, Bambas feels like a failure, frustrated in his cultural aspirations and bored by his predictable family life. However, the film does not conform to the expected satire of young, sophisticated city-dwellers mocking and despising country folk who are unaware of their backwardness: the relationship is modulated by a mutual exchange of gazes. The film's rural characters are sympathetic, self-aware, and take a good-humoured approach to life's challenges.

With an even greater sense of documentary realism than Loves of a Blonde, Intimate Lighting is a film in which the objects present are fully justified by the context and fit seamlessly into everyday life. Nonetheless, these objects can take on a symbolic resonance that is clear without being contrived. The additional layers of meaning that objects acquire derive both from the circumstances in which they appear and from the obvious preoccupations of the characters, preoccupations which constitute the film's theme.

As this film showcases the tension that arises from the social pressure on guests and hosts to conform to their roles, one theme which naturally arises is the difficulty of maintaining a dignified façade. Chickens and their related foodstuff consistently intervene to disrupt any attempts to put up such a front. (1)

As live animals, chickens thwart Bambas's attempt to keep his car presentable. The first time he opens the garage doors, there is a chicken standing on top of the car: a Surrealist juxtaposition, certainly, but not at all gratuitous. However much Bambas loves his family, his car is tacitly associated with the freedom of his unmarried life, a part of himself that he would like to keep sacrosanct. However, the chickens invariably find their way into his garage, making it (as Bambas bitterly observes) 'more like a hen house'. The fact 


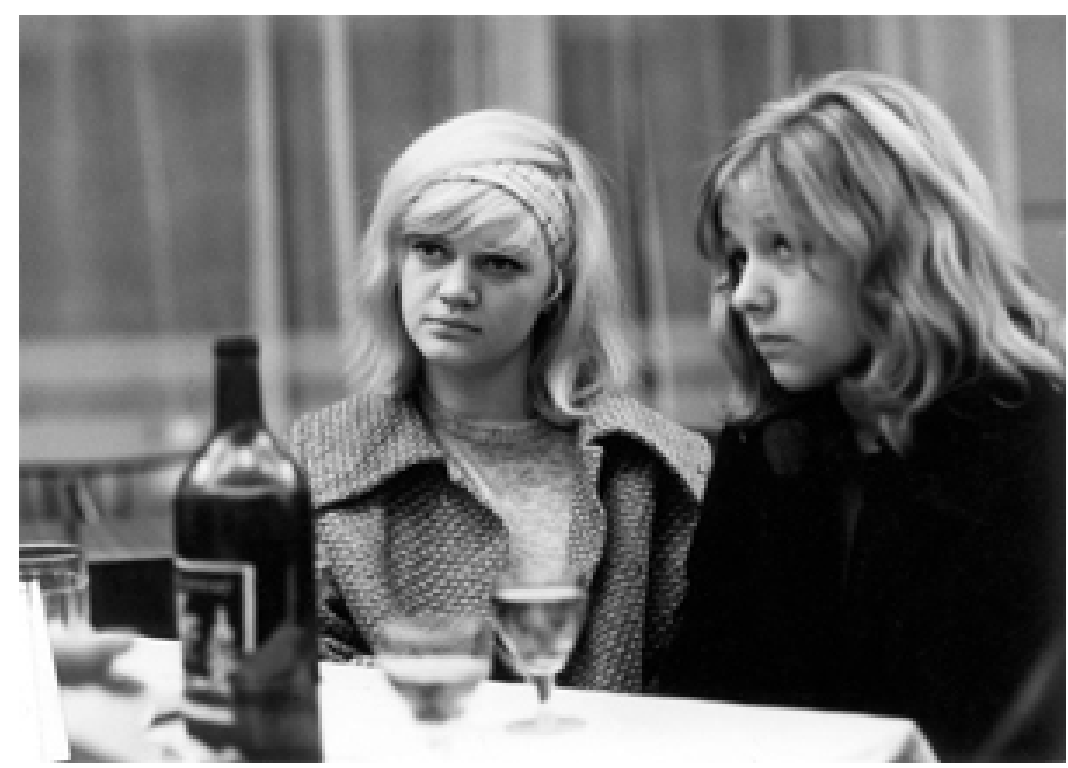

Figure 1: Loves of a Blonde (Hana Brejchová as Andula, left)

that they have colonized the garage in order to 'hatch' reinforces the symbolic confrontation of his family obligations with Bambas as an individual. Bambas angrily tries to chase the chickens out of the garage, while his mother-in-law protests that he is scaring them and that 'they'll stop laying eggs'. This minor confrontation highlights differing perspectives on the chickens: Bambas's overreaction shows that he sees them as more than a minor inconvenience, as they stand as constant proof of the lack of privacy in his life. The grandmother, meanwhile, is focused on the chickens as living creatures and, above all, valuable livestock. It is the grandmother's perception of the animals that is emphasized most at the end of the scene when a chicken is run over as Bambas impatiently drives the car while the chicken is still underneath it. In the scene's final shot, the camera pans down from the rear of the car to follow an egg rolling back into the garage until it bumps into the chicken that lies with a broken neck. There is a sense of sadness here for the lost domestic animal, but no sinister undertones of a desire in Bambas to do away with his family. Indeed, the cut from the chicken to the funeral procession that begins the next scene serves to mock the sadness the audience may feel for the dead chicken, as the montage creates a brief but fallacious impression that the chicken is being mourned.

When the image of the chicken on the car recurs later in the film, its contrast with the shot immediately preceding it again symbolises Bambas's frustration. Caught by car headlights, Bambas and Petr cut a lyrical silhouette as they drunkenly head off together to pursue their dream of a free life on the road. The next shot comes as a contrast, as it combines car and chicken to create the very image of Bambas's perpetual defeat: here, there is just one vehicle, and it is confined to the garage; as it is now morning, the car's headlights appear weak; the silhouettes of the two men have been replaced by the more prosaic and terribly familiar outline of the chicken on top of the car.

Elsewhere in the film, chickens and eggs as food serve as catalysts to undermine the gravity of ritual and hospitality. For example, when the family and their visitors first sit down together for a dinner of roast chicken, Bambas's wife attempts to give the guests the best cuts. She is foiled, though, by her family's greediness and her guests' generosity: Štěpa and Petr are faced with the parson's nose, which they have to share. The children squabble over the chicken leg which winds up flying across the table. Bambas and his wife cannot be more embarrassed than Petr, however, who must apologize for his childish girlfriend as she begins laughing uncontrollably. The chicken's association with rural life brings, in addition, a natural, erotic element to the scene's humour, giving the object a sexual resonance: the grandfather clearly desires Štěpa's chicken leg, and presents her with the parson's nose in exchange.

The next time the adults assemble at the table is at the end of the film, to drink home-made egg-nog. Having 
gone through the ceremony of proposing a toast, they all lift their glasses but find that the thick drink will not budge. 'A bit of patience, that's what we need', says the grandmother, and as the film ends, there is a shift from a full shot to a long shot of the group with their glasses still resolutely glued to their lips and their heads tilted back. The egg-nog is the embodiment of the adjective 'domácí' ('home-made'), a quality lauded elsewhere in the film: special food that here, in its consumption, recalls the patience required in its preparation. At the same time, the presence of this object creates a humorous acknowledgement that such perseverance may appear ridiculous to outsiders.

\section{Jan Němec's The Party and the Guests}

The Party and the Guests allegorizes the power dynamics of authoritarian government with a narrative focused on a group of friends who have been invited to an open-air banquet in the countryside. The host of the party at first seems affable but eventually demonstrates an irritable and controlling side when one of the guests leaves early. The host's adoptive son and his gang play a frightening trick on the friends, bullying them and taking them prisoner before the banquet.

The film introduces a sense of unreality through nightmarishly absurd events and situations which distance it from the quality of documentary realism that has characterized the films examined so far. Němec believed that 'the director must create his own world...a world independent of reality, as it appears at the time' (Němec interviewed in Hames 2005: 166). His aim was that the audience should cease to be concerned with realism and instead focus on 'what the director really tries to convey' (Němec interviewed in Hames 2005: 166-67). Nonetheless, the allegory in The Party and the Guests made the film's relationship to reality clear enough for it to be banned immediately after its release, and Němec himself was banned from the nationalized Barrandov Studios soon afterwards (Hames 2007).

Peter Hames has remarked on the way in which Němec's films 'encourage you to interact' with them (2007). This is due in large part to the fact that they provide key elements of a familiar everyday reality and highlight ambiguity within that reality. Such ambiguity, which exists in events, dialogue and, most importantly for this article, objects, can be seen as both rupturing the surface of reality and making that reality more convincing. Objects in The Party and the Guests take on a dual meaning which contributes to a darkly humorous reflection of the discrepancy between official façades of order and reason and practical states of violence and corruption in authoritarian government. However, certain ambiguities of this satire on a specific political system highlight a more general hypocrisy in human relationships. Such ambiguity may be unrealistic in the context of the film, and constitute an exaggeration of the reality of both authoritarian systems and human interaction. Nonetheless, there is a basic, haunting truth in the notion that the meaning of words, situations and objects can be shifting and unstable.

Past studies of this film have tended to focus on dialogue rather than image (Hames 2007), but the two in fact work in a similar manner, and objects are thematically at least as important as dialogue. The film's writer, Ester Krumbachová, used 'dialogue...to convey its absurdity, or alternatively, a reality beyond the apparent meaning of words' (Hames 2005: 182). There is, however, also (to adopt Krumbachová's terms) an absurdity in the characters' relationship with objects, based on a disturbing reality that exists beyond objects' apparent meaning. There are two different types of ambiguity relating to objects in this film: ambiguity with a clearly political resonance, and ambiguity with a more general relevance to human relationships. The fact that the film presents the general ambiguity before moving on to the political one serves to intensify the film's criticism of society: it suggests that the more dangerous political ambiguity naturally developed from the seemingly innocuous social one.

Němec begins with the more familiar type of ambiguity found in everyday social situations. Material things in the film initially seem to be no more than pleasurable accessories to life, as they are in reality (or as one likes to think that they are). The film opens with an extreme long shot of the group of friends in a country setting, having their own private picnic before the official banquet. This first scene evokes old-fashioned Romantic images of urban dwellers enjoying a day in the country, as Renoir père would have painted them. The friends flirt, recall other happy occasions, dream about the future, and enjoy the present moment. The women's arms and legs are bare, and almost all of the shots are medium close-ups showing just the shoulders and faces of the guests, adding to the intimacy and joyful sensuality of the moment. However, the cake that they are eating also has its own close-up, and such shots of food are carefully arranged, leading Peter Hames 


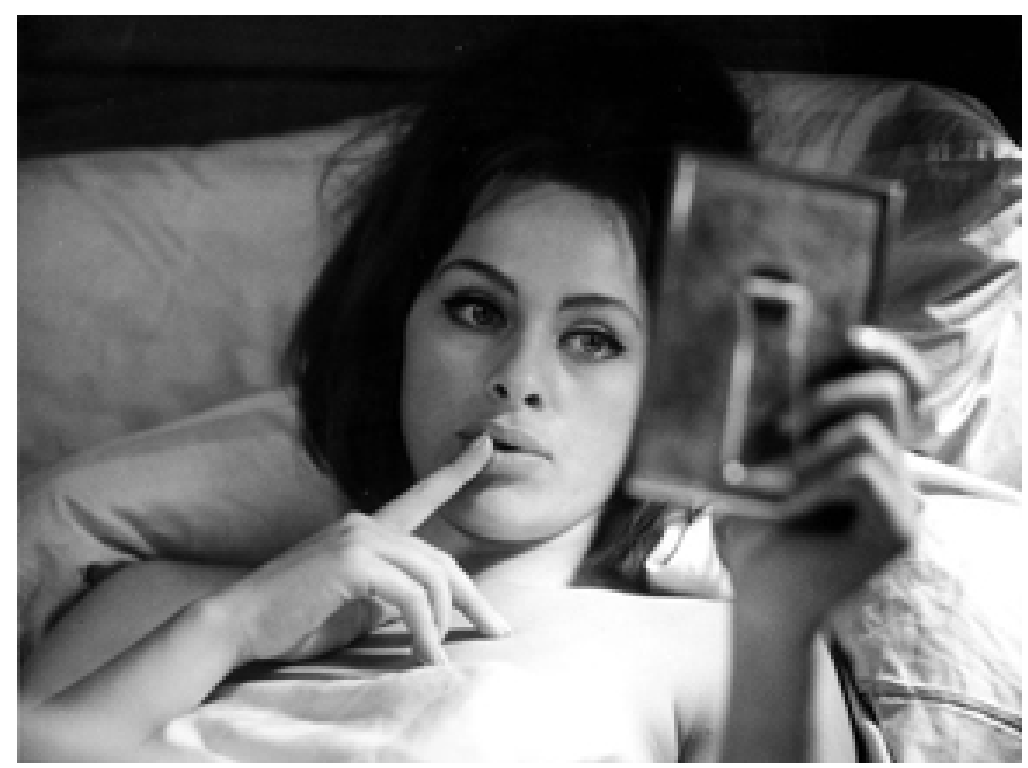

Figure 2: Intimate Lighting (Věra Křesadlová as Štěpa)

to compare the images to Dutch still life painting (2007).

The camera assiduously follows the slices of cake as they are passed around, then dwells in medium close-up on the actors, emphasising the moment of eating. Food thus begins to take part in the sensuality of the moment, and continues to do so in subsequent shots. When one man compliments a woman on the excellent cake she baked, her cleavage is on show as she laughs. One of the men brings alcohol back from the river, and a detail shot shows him playfully placing one of the cold bottles against his neighbour's bare arm, making her cry out. She later steals one of the men's shot glasses and the camera shows her face in profile, close-up, as she drinks it down. Soon after, the camera follows one of the men as he drains his glass and reclines for a nap in a single movement. There is a close-up of another woman as she lazily stretches out a piece of gum she is chewing. By this point, the viewer may have noticed that the sensuality of the scene, like much of the conversation, is not only influenced by edible objects, but actually relies on them. The woman who initially declared, 'I like good fun, good company, and good food', by the end of this relatively short scene has already shifted the emphasis of her desires: 'I like nice, well-looked-after things', she states complacently.

The following scene also evokes Romantic paintings, of bathers this time, as the women, aesthetically arranged along the river, wash in preparation for the party. Here again, the film differs radically from traditional depictions in that the focus of sensuality shifts from the women's bodies to material things. The conversation revolves around the perfume one woman's husband gave her as a gift, or concerns about whether a country walk will ruin their high heels. The camera trails the bar of soap as it is passed around; it focuses on the fastening of a stocking to a garter belt rather than the leg that supports them; it follows a dress as it is slipped over a woman's head, as though unconcerned with her body.

If these first two scenes emphasize objects in an unusual way, the audience may still feel indulgent towards the characters' apparent materialism, not yet having understood its full extent or significance. However, by the final scene of the film, the audience will have discovered the true shallowness of the majority of these characters. When the search party decides to take along a vicious dog to follow the scent of the missing guest, that guest's wife is only concerned that the dog might tear her husband's new suit. Similarly, another guest whose bag was damaged as part of a joke, declares without a hint of irony, 'Stuff the bag. I don't give a damn about it. But what about my knife and lighter?' Although he concludes by saying, 'I'm not bothered about those either. It's the principle I'm bothered about', this last assertion, arriving so late, rings hollow. The host's promise to replace the knife and lighter is received with applause, and the guest and his principle are placated. 
Němec's treatment of objects thus leads to a change in the audience's understanding of these objects' significance in the context of the film. This mirrors the audience's developing perception of characters and situations, as they discover the inhumanity that exists behind façades of playful or considerate behaviour. Objects in this film, then, become hybrid in an ingenious and disturbing way: those objects which at first seem relatively insignificant actually have more power over the characters than higher principles such as justice and humanity. The fact that the spectator does not immediately suspect the exaggerated importance of objects, which nonetheless existed all along, makes the power of the objects all the more sinister in retrospect.

Shortly after the first and second scenes which hint at the unexpected degree of the characters' material obsessions, Němec introduces a duality more directly relevant to the film's political satire. Verbal and visual methods are used to associate objects with a threatening use in addition to their innocuous one. For example, the host's adoptive son, as part of his so-called joke, has a desk set up in the middle of a forest clearing, and sits behind it with a black folder, the contents of which are unknown. An undercurrent of aggression quickly overwhelms any initial amusement that the audience may feel at the ease with which an office is set up outdoors. Benign absurdity ceases to be the focus, as the terror of unexplained detention and potentially violent interrogation dominates. When the host arrives to rescue the victims of the joke, he demands that the desk be put back in its original location as part of the banqueting table, and seizes the black folder which turns out to be the guest list.

Although it may seem at this point that the objects have returned to their everyday significance as unthreatening items, the spectator quickly discovers that even when the desk is part of an open-air dining table and the black folder contains the names of 'honoured guests', the innocuous meaning no longer exists except as a façade for the threatening reality, because the situation is still one of coercion. This is confirmed when the host notices that one of the guests has left the banquet, and dual meanings are mobilized in another object. A search party is formed, and it is suggested that a gun should be fired when the missing guest is found so that the other guests know to stop looking for him. The overtly stated use of the gun, then, is as a harmless way of signalling a piece of information. However, just before the search party was formed, and before the gun was ever produced, the host's son spontaneously expressed a desire to shoot himself and described this fantasy in lurid detail. If it was ever possible for a gun to make an innocent appearance in a film, the violent images which the son evoked render it impossible in this case: the reference to a gun immediately turns the search party into a hunt. The threat of violence is reinforced physically as well as verbally shortly after the search party has left, as the guest who has become the host's favourite idly aims the gun across the lake while he addresses an interrogation-like series of questions to the missing guest's wife.

This latter set of examples has a political resonance in that it demonstrates how individuals who are in control may, through an unspecified threat, activate a terrifying significance in objects, even if the stated use of those objects is innocuous. A peaceful and reasonable façade is maintained by pretending that the stated significance of objects is the real one, while never explicitly acknowledging the very real existence of threat. The obvious political relevance in these examples is that if one does not speak out and identify the reality of a situation, a manipulative and violent regime may claim legitimacy by creating a false façade of harmony. However, the film also suggests that a disturbing degree of selfishness underlies the façades of harmony that people like to maintain in social situations in general, and that political corruption is simply an example of this same discrepancy on a larger and more menacing scale.

\section{Conclusion}

Consistently granting primacy to physical reality rather than the unconscious realm was specific to the Prague Surrealist group. However, recognising the rich potential in everyday environments was typical of Surrealism in general, and was exemplified by the Paris group's writings on Surrealist objects. In L'Amour fou (Mad Love, 1937), André Breton recounted his experiences with Giacometti at the Paris flea markets, where they found that the objects which drew their attention frequently corresponded to a deep personal preoccupation (1992a: 697-700). The Surrealists were fascinated by this sense that the world is shaping itself according to one's own needs, as it demonstrated the previously unsuspected power of the unconscious over what we believe to be our objective perception of our surroundings. In addition to these highly personalized Surrealist objects, the Surrealists identified a number of ways in which the unconscious could be encouraged to engage with an object in a creative manner, revolutionising one's usual perspective on the world. The classic 
example, and inspiration for this practice, was a line from the Comte de Lautréamont's poem Les Chants de Maldoror (The Songs of Maldoror), which described 'la rencontre fortuite sur une table de dissection d'un parapluie et d'une machine a coudre/the chance meeting of an umbrella and a sewing machine on a dissecting table': in other words, the juxtaposition of two objects which are not normally found together (Breton 1992b: 492).

Many of the objects highlighted in the three films discussed here may be considered to be Surrealist objects of a sort: the juxtaposition of a necktie and a tree in Loves of a Blonde, for example, or the open-air office in The Party and the Guests. For many of the objects discussed, meaning was modulated by the personal preoccupations of the film's characters: while Bambas saw the chickens in his garage as a depressing symbol of his defeated ambitions, to his mother-in-law the animals were only there to produce eggs.

Of course, the principal objection to classifying objects in film as 'Surrealist objects' is that the complex unconscious component is frequently missing: it is impossible to predict which objects in any particular film may hold personal significance for any individual audience member. Similarly, films classically have difficulty in conveying the psychology of their characters in as complete a manner as literature, and as a result, will typically offer only a simplified account of the multiple and profound personal preoccupations to which a Surrealist object was supposed to respond. When the Paris Surrealists attempted to make films which would explore the unconscious in an ambitious way, they constantly came up against problems which would prove insurmountable: the audience dismissing their oneiric films as 'just dreams', or the Surrealists themselves finding that the technology available to them was not sufficient for portraying the vast riches of the unconscious where the impossible can occur and contradictions may coexist. Nonetheless, the films examined here do highlight an instability in the meaning of everyday objects: depending on the person and the situation, one object may have many possible meanings, and this communicates something of the perspective of the Surrealists, who saw everyday experience as being more significant and full of greater possibility than was typically acknowledged.

In those films that the Czech Surrealists admired most, quasi-Surrealist objects were not the result of a specific commitment to portraying the richness of everyday surroundings, but a consequence of historic and stylistic factors. One stylistic factor was a tendency towards humour, whether dark or more light-hearted, and basing such humour on differing interpretations of objects proved particularly fruitful for these film-makers. More intriguing, though, is the way in which the political situation in 1960s Czechoslovakia may have influenced the directors' attitude towards objects. The film-makers were stimulated by the new permission to portray everyday life: unlike the clear-cut propaganda of Socialist Realism which preceded it, Czech New Wave films' portrayal of contemporary reality naturally included its complexities and contradictions. At the same time, censorship still existed: if a director wanted to make more contentious political statements, ambiguity was again useful.

This study of the concerns shared by Czech Surrealism and the documentary-influenced strand of Czech New Wave filmmaking has identified a possible characteristic of filmmaking under restrictive regimes, and topic for further research. By including everyday objects with many possible interpretations in their films, directors in countries where political and personal freedom is developing (but not yet complete) may, on the one hand, circumvent censorship and, on the other, participate in a growing exuberance at the new-found potential in everyday life: as it was put so lyrically in May 1968, 'l'imagination au pouvoir/power to the imagination', a concept with which the Surrealists would surely have agreed.

\section{Notes}

1. though live animals cannot be defined as objects, the fact that here and in other Czech New Wave films they also make appearances as inanimate food items justifies consideration of the resonance that the animals take on when they are alive. 


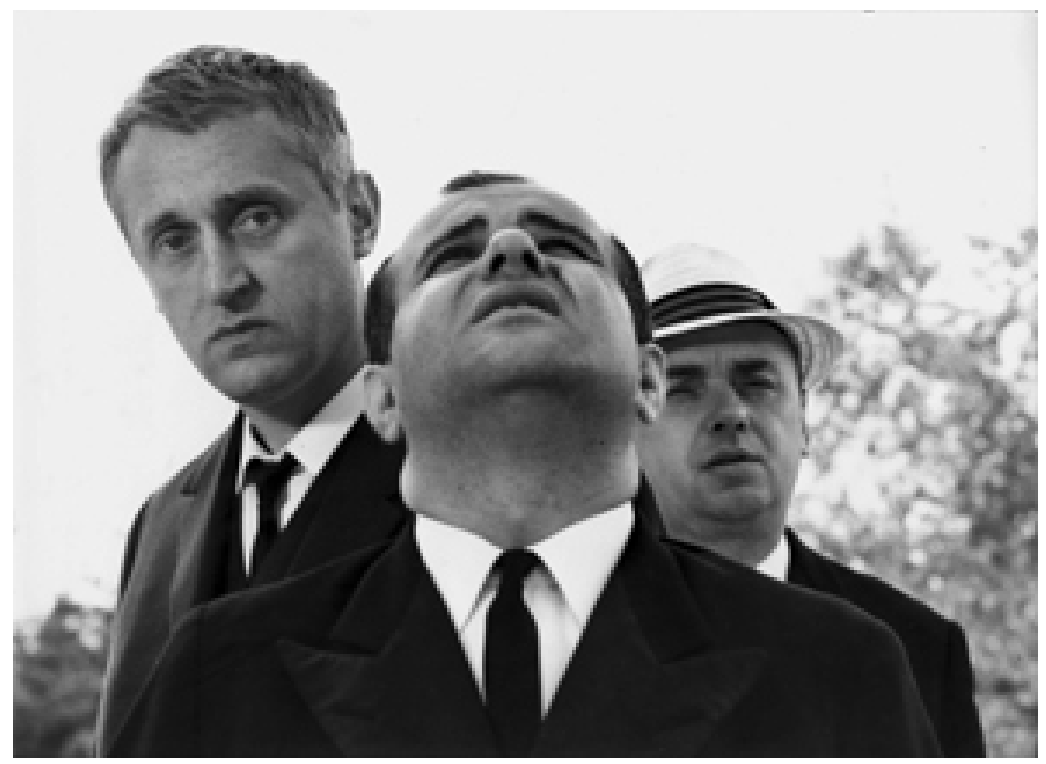

Figure 3: The Party and the Guests: the Missing guest (Evald Schorm, left)

\section{References}

Bregant, Michal (1996), 'Le cinéma d'avant-garde: entre le rêve et l'utopie', in E. Zaoralová and J. L. Passek (eds.), Le Cinéma tchèque et slovaque, Paris: Editions du Centre Pompidou, pp. 75-83.

Breton, André (1992a), L'Amour fou, in M. Bonnet (ed.), Breton: Euvres complètes, vol. 2 of 3 vols., Paris: Gallimard, pp. 673-785. First published 1937.

(1992b), Position politique du surréalisme, in M. Bonnet (ed.), Breton: Euvres complètes, vol. 2 of 3 vols., Paris: Gallimard, pp. 472-96. First published 1935.

Buchar, Robert (2004), Czech New Wave Filmmakers in Interviews, Jefferson, NC: McFarland.

Chytilová, Věra (1966), Sedmikrásky/Daisies, Prague: Barrandov.

Forman, Miloš (1965), Lásky jedné plavovlásky/Loves of a Blonde, Prague: Barrandov.

Hames, Peter (2005), The Czechoslovak New Wave, $2^{\text {nd }}$ ed., London: Wallflower.

(2007), 'An Appreciation by Peter Hames', on Second Run DVD release of The Party and the Guests.

(2008a), 'The Core of Reality: Puppets in the Feature Films of Jan Švankmajer', in P. Hames (ed.),

The Cinema of Jan Švankmajer: Dark Alchemy, $2^{\text {nd }}$ ed., London: Wallflower, pp. 83-103.

(2008b), 'The Film Experiment', in P. Hames (ed.), The Cinema of Jan Švankmajer: Dark Alchemy, $2^{\text {nd }}$ ed., London: Wallflower, pp. 8-39.

(2008c), 'Interview with Jan Švankmajer', in P. Hames (ed.), The Cinema of Jan Švankmajer: Dark Alchemy, $2^{\text {nd }}$ ed., London: Wallflower, pp. 104-39.

(2009), Czech and Slovak Cinema: Theme and Tradition, Edinburgh: Edinburgh University Press.

Král, Petr (1983), Le Surréalisme en Tchécoslovaquie, Paris: Gallimard.

(2002), 'D'un Imaginaire réaliste', in P. Král (ed.), Le cinéma des surréalistes tchèques, Cognac: Temps

qu'il fait, pp. 3-10.

Němec, Jan (1966), O slavnosti a hostech/The Party and the Guests, Prague: Barrandov.

Passer, Ivan (1965), Intimní osvětlení/Intimate Lighting, Prague: Barrandov. 
Škvorecký, Josef (1971), All the Bright Young Men and Women: A Personal History of the Czech Cinema, trans. M. Schonberg, Toronto: Peter Martin.

Šmejkal, František (1989), 'From Lyrical Metaphors to Symbols of Fate: Czech Surrealism of the 1930s', trans. P. Wilson, in Czech Modernism: 1900-1945, Houston: The Museum of Fine Arts Houston, pp. 64-83.

(1990a), 'After Devětsil: Surrealism in Czechoslovakia', in R. Švachá (ed.), Devětsil: The Czech AvantGarde of the 1920s and 30s, Oxford and London: Museum of Modern Art and the Design Museum, pp. 88-93.

(1990b), 'Devětsil: An Introduction', in R. Švachá (ed.), Devětsil: The Czech Avant-Garde of the 1920s and 30s, Oxford and London: Museum of Modern Art and the Design Museum, pp. 8-27.

\section{Author Information}

Alison FRANK received an Honours BA from the University of Toronto (Trinity College), an M.St. in European Literature and D.Phil. in Modern Languages from the University of Oxford (Keble College). A member of FIPRESCI, she currently works as a freelance film critic based in London. 